\title{
A Study on Energy and Cost Efficiency for Existing Hotel Buildings in Turkey
}

\author{
Dr.Merve Atmaca ${ }^{1, *}$, Prof.Dr.Zerrin Y1lmaz ${ }^{2}$ \\ ${ }^{1}$ Tc. Beykent University, Faculty of Engineering and Architecture , Istanbul, Turkey \\ ${ }^{2}$ Istanbul Technical University, Faculty of Architecture , Istanbul, Turkey
}

\begin{abstract}
In Turkey, according to TUIK Sectoral Energy Consumption Statistics (2006), the hotel buildings with the highest share, constitute $35 \%$ of the total building energy consumption. Energy needs and consumption behaviours differ according to the typology of the building. Energy Performance of Buildings Directive (EPBD) has been adapted to the conditions of Turkey to increase energy and cost efficiency, to reduce the environmental and economic negative effects. The energy consumption and the global cost were investigated under different conditions in an existing hotel building. The paper is unique in its ability to deliver optimum solution through comparison by evaluating energy and cost efficiency at the same time considering sectoral, climatic, technological and economic national conditions when the literature research detailed in the present works about the problem is evaluated in detail. All findings have been compared simultaneously under different climate regions of seasonal and yearly working conditions of selected test hotel to obtain the energy and cost efficiency. Among the proposed improvement scenarios, the optimum scenario is determined in terms of cost and energy efficiency in S18 which has the highest energy efficiency. In this case, both insulation material type and thickness as well as glass type can be bent and through multiple measures can be achieved by $25.7 \%$ improvement for energy efficiency.
\end{abstract}

\section{Introduction}

Due to migration and rapid population growth, the energy demand in our developing country is increasing rapidly. Turkey's Gross National Product per consumed representing the amount of primary energy and the energy density is an indicator used in all around the world is more than twice the European Union.

The per capita energy consumption in Turkey, which was $1493 \mathrm{kWh}$ in 2000 , increased by approximately $80 \%$ to $2,682 \mathrm{kWh}$ in 2014 [1]. When primary energy consumption is taken into consideration as of 2016, Turkey take place on the rank 19th among all the countries in the world with 129.3 MTEP. Turkey's electricity consumption was go up 65.7 billion $\mathrm{kWh}$ increasing doubled in 2015, which was 132.6 billion $\mathrm{kWh}$ in 2002. According to Ministry of Energy in Turkey, about one third of the energy produced is consumed by buildings in 2005 [2].

On the other hand, there is the potential to minimize the amount of energy consumption in buildings by ensuring the efficient use of the energy produced maintaining the comfort conditions. According to the sectoral reports by the Ministry of Energy, the saving potential rate is $30 \%$ in buildings, $20 \%$ in industry and $15 \%$ in transportation [3]. When the energy consumption data is analyzed by sector, it is seen that the energy consumed by the buildings is the highest in the service sector after the housing and office buildings. In the service sector, the largest energy consumption rate is $35 \%$ for the hotel/ accommodation [4]. Since the cost of energy consumed is at the top of the expense items, many researchers and hotel managers concentrated their attention on the amount of energy consumption. The average daily electricity, water and fossil fuel consumption per person in 5-star hotels is given in Table 1.

Table 1. The average daily energy consumption in hotels

\begin{tabular}{|l|l|l|}
\hline Electricity & Water & Liquid Natural Gas \\
\hline $21-22 \mathrm{~kW}$ & $420-440 \mathrm{~L}$ & $7-10 \mathrm{~L}$ \\
\hline
\end{tabular}

Given World Tourism Organization, 2017 data in terms of tourism revenue and tourist numbers one of the top ten countries is Turkey. There are so many tourism types such as summer/sea tourism, winter/mountain sports tourism, plateau tourism, commercial/convention hosting the city tourism because of seasonal, historical and cultural reasons.

The energy efficiency of the large hotel buildings such as 5-star hotels and resorts should be considered differently from the other building types such as residential and commercial buildings because of the fact that they contain variable building geometry, many different functional spaces, and different working time schedules.

\footnotetext{
* Corresponding author: $\underline{\text { merveatmaca } @ \text { beykent.edu.tr }}$
} 
According to Distribution of Foreign Tourists Visited Turkey as of Years and Months, 2017 during the six months of summer tourism, including May and October, it welcomes foreign tourists about three times more than the other six months [5].

It is an indisputable fact that the way to reduce energy consumption and energy costs in buildings is possible by increasing energy and cost efficiency.

\subsection{Building Efficiency Parameters}

\subsubsection{Building Energy Parameters}

Building energy performance is the amount of energy consumed to meet the standard requirements of heating, cooling, ventilation, lighting and hot water in accordance with the comfort conditions depending on the function of the evaluated building [6].

Building efficiency parameters can be summarized as climate data, location, orientation, form, obstacle status, building shell, usage charts, domestic earnings, natural ventilation, active heating systems, active cooling systems, active ventilation systems, lighting systems, hot water systems, renewable energy systems.

\subsubsection{Cost Efficiency Parameters}

The effects of global cost effectiveness are on building and material life, initial investment, renovation costs, heating, cooling, lighting, hot water, fans and pumps, and other energy consumption. quantities, energy unit prices, subscription and access fees, building life cycle, inflation rate, market interest rate, real interest rate, the value at the end of the calculation, discount rate, maintenance and repair costs [7].

Global cost variables are the initial investment cost, renovation cost, operating cost, life cost.

\subsubsection{Comfort Parameters}

Comfort parameters evaluated in building as thermal comfort and visual comfort.

Thermal comfort means that people should be in a certain comfort while maintaining their physical and mental activities in terms of climate conditions such as temperature, humidity and air flow. Indoor temperature is the most important parameter for thermal comfort. The indoor temperature should be at a level where people feel comfortable according to the function of space for winter and summer situations. The ideal indoor temperature varies depending on the type of work being done and clothing factor. The amount of moisture in the indoor environment is another factor that determines thermal comfort. In most sources, it is recommended to have a relative humidity of $30-80 \%$. A suitable air flow rate must be provided to ensure thermal comfort and to remove gas and dust that are harmful for human health. It should be ensured that the air flow rate does not exceed 0.3 to 0.5 meters per second.
Visual comfort, physiological and psychological comfort are combined. Physiological comfort is related to the measurable values of the lighting (quantity), psychological comfort, the undetectable values of the lighting (quality). Some of the important parameters discussed for visual comfort assessment are lighting level, glare, maintenance factor.

\subsection{Nearly Zero Energy Building}

Energy requirement is very low, with very high energy performance and the required amount of energy is mostly defined as the building from which renewable energy sources are met.

For the term lem very high energy performance as defined in this definition, there is no regulatory standard value and each EU member country is expected to determine this level in accordance with its national requirements through calculations.

Approximately zero energy building concept, cost in the same directive is directly related to the concept of optimum energy efficiency.

Cost optimum energy efficiency level is defined as energy performance level which results in the lowest cost during the economic life period according to Energy Performance of Buildings Directive (EPBD) Recast and this level is until the end of 2020, it is aimed to catch the zero energy level [8].

\subsection{Net Zero Energy Building}

Net Zero Energy Building is defined as a building that has a very low energy demand, has a very high energy performance, and is able to supply all or more of the required amount of energy from renewable energy sources and sell some of the renewable energy produced [9].

\section{Methods}

Many of the National Calculation Methods are concerned with the calculation of the initial energy consumption of buildings, but the determination of the calculation stages and the relevant energy needs varies from country to country. Exterior temperature and indoor comfort conditions vary from country to country. Therefore, although the performance evaluation criteria are the same, building performance calculation models differ from country to country due to differences in climate conditions and comfort conditions.

EN 13790, an umbrella document, proposes three different precision methods for the calculation of Building Energy Performance. The detailed dynamic method of these methods is an overly detailed and impractical method for the building energy certification method which takes into account the interaction of the umbrella document between the simultaneous, multizone zones in buildings, directed by the EN 15265 Standard for the Calculation of the Energy Needed in Ambient Heating and Cooling Using Dynamic Methods for Buildings [10]. It is necessary to evaluate the energy 
performance and greenhouse gas emissions of complex buildings with a large number of thermal zones having different requirements.

In 2010, the renewed directive (EPBD Recast) envisages a combination of the energy and cost effectiveness of buildings and calculates the building energy consumption in terms of primary energy using detailed dynamic methods.

In the calculation of energy consumption, detailed dynamic calculation method is developed and widely used by the US Department of Energy (DOE) EnergyPlus V8.1. software is used. The building and building environment is defined by the threedimensional modeling program SketchUp and OpenStudio.

Detailed dynamic simulations, heating, cooling, lighting, equipment and other energy consumption, total energy consumption, comfort conditions and mechanical system component sizes are obtained for different time intervals, such as hourly, daily, monthly yearly and so on.

\subsection{Local Inputs}

One of the most critical points of building energy performance simulations is that the input data of building energy performance parameters is correctly defined. Climate data is of great importance among these parameters. Climate data can be obtained from climate data contained in EPlus. Turkey's prepared for all cities outside temperature, wind and humidity values for longterm averages Excel interface with EPlus meteorological data was revised and the case can be brought close to the truth.

In Turkey, taking into account the social and cultural structure of the hotel industry study timelines, comfort conditions of the input data must be defined correctly.

Turkey's economic conditions for cost analysis have been performed of the global cost of using national data.

For local building materials, the thermophysical and technical properties of the material must be correctly defined.

\subsection{Steps forming the approach}

The basic steps for the approach are given in Table 2 [11].

Table 2. The steps of the approach.

\begin{tabular}{|l|l|}
\hline S1 & Identification of existing hotel building parameters \\
\hline S2 & Energy analysis for existing hotel building \\
\hline S3 & Global cost analysis for existing hotel building \\
\hline S4 & Evaluation of the current situation \\
\hline S5 & $\begin{array}{l}\text { Determination of improvement scenarios for } \\
\text { passive and active energy systems }\end{array}$ \\
\hline S6 & Energy analysis for improvement scenarios \\
\hline S7 & $\begin{array}{l}\text { Performing global cost analysis for improvement } \\
\text { scenarios }\end{array}$ \\
\hline S8 & $\begin{array}{l}\text { Selection of cost-optimal energy improvement } \\
\text { scenario }\end{array}$ \\
\hline
\end{tabular}

\subsection{Calculation of primary energy consumption for existing hotel building}

The consumption calculated to compare the energy consumption of the scenarios where the existing building and improvement packages are applied on an equal basis should be converted to primary energy type [12].

In Turkey, for electrical primary energy conversion coefficient is 2.36 for natural gas and other fuels are 1 .

$$
\begin{gathered}
B E(\mathrm{e})=T_{\mathrm{EET}} * 2,36 \\
B E(\mathrm{~d})=T_{\mathrm{DET}} * 1 \\
T B E=B E(\mathrm{e})+B E(\mathrm{~d})
\end{gathered}
$$

$B E$ (e): Total primary electrical energy consumption $B E$ (d): Total primary consumption of other energy sources

$T_{\text {EET: }}$ Total electrical energy consumption

$T_{\text {DET }}$ : Total consumption of other energy sources

$T B E$ : Total of primary energy consumption

\subsection{Calculation of carbon emission for existing hotel building}

The variable carbon emission coefficients are multiplied by the relevant fuel consumption and the annual carbon emission of the whole building is obtained by equality (4).

In our country, carbon emission conversion factors are 0.234 for natural gas, 0.626 for electricity and 0.33 for liquid fuel [13].

$$
E_{\mathrm{CO} 2}=\left(e_{\mathrm{dg}} * 0.234\right)+\left(e_{\mathrm{e}} * 0.626\right)+\left(e_{\mathrm{sy}} * 0.33\right)
$$

$E_{\mathrm{CO} 2}$ : Total Building Carbon Emission

$e_{\mathrm{dg}}$ : Energy consumption from natural gas

$e_{\mathrm{e}}$ : Electricity consumption

$e_{\text {sy }}$ : Energy consumption by liquid fuel

\subsection{Calculation of initial investment costs}

The initial investment cost can be divided into three main categories: direct cost (materials, transport and labor), indirect costs (infrastructure, contracting assistance, overhead) and taxes.

To determine the direct cost of materials, it is more reliable to average the costs collected from three different construction material suppliers $25 \%$ of the direct cost in Turkey are assumed to be equal to the indirect costs [14].

$$
C I_{\mathrm{n}}\left(\mathrm{S}_{\mathrm{n}}\right)=C I n(\mathrm{p}) *\left(1+R_{\mathrm{d}}(\mathrm{i}) / 100\right)^{\mathrm{T}}
$$

$C I_{\mathrm{n}}\left(\mathrm{S}_{\mathrm{n}}\right)$ : Initial investment cost (for each step)

$C I n(\mathrm{p})$ : Today's initial investment cost

$R_{\mathrm{d}}$ : Discount rate for implementation year

$T$ : Application year

\subsection{Calculation of global cost analysis for existing hotel building}


The global cost calculation method takes into account the increasing value for the equipment that has a life span of more than the building life, falling from the total cost.

For global cost analysis, the global cost calculator is prepared with the equation (6) through Microsoft Excel software. The inflation rate used in the calculations was $8.1 \%$ for 2015 and $14.3 \%$ for the market interest rate [15].

$$
\operatorname{Cg}(\tau)=C I n+\sum_{j}\left[\sum_{i=1}^{\tau}(C y(\tau)+C r(\tau))-V f, \tau(j)\right]
$$

$C g(\tau)$ : Global cost

CIn: First investment cost

$C y(\tau)$ : Operating costs (maintenance, operation and energy costs)

$\mathrm{Cr}(\tau)$ : Renewal cost

$V f, \tau(j)$ : The last value of component $\mathrm{j}$ corresponding to $\mathrm{T}$ year

\section{An existing hotel building in Turkey}

Turkey in accordance with the conditions, in order to determine the improvements to be made in the existing hotel building scenario is compared to the findings obtained from energy and cost analysis of an existing hotel building.

\subsection{Identification of the sample existing building}

The present example building is a four-story, four-star seasonal tourism facility consisting of a basement, a ground floor and two bedrooms. The hotel has 84 rooms, including 6 corner suites and 78 standard rooms. Functional facilities in the hotel, 24-hour café-bar, multipurpose hall for 200 people, foyer, à la carte restaurant for 80 people, kitchen, warehouses, cold storage, public toilets, hairdresser, infirmary, offices, Turkish bath, sauna, massage, gym, lobby and laundry facilities.

This hotel is located in the touristic town in the Aegean region, Bodrum. The building is designed in $\mathrm{U}$ form as shown in the Figure1 so that all rooms can benefit from the view. Balconies are organized gradually so as not to interfere with each other. At the same time, it serves as a sunshade fringe for windows.

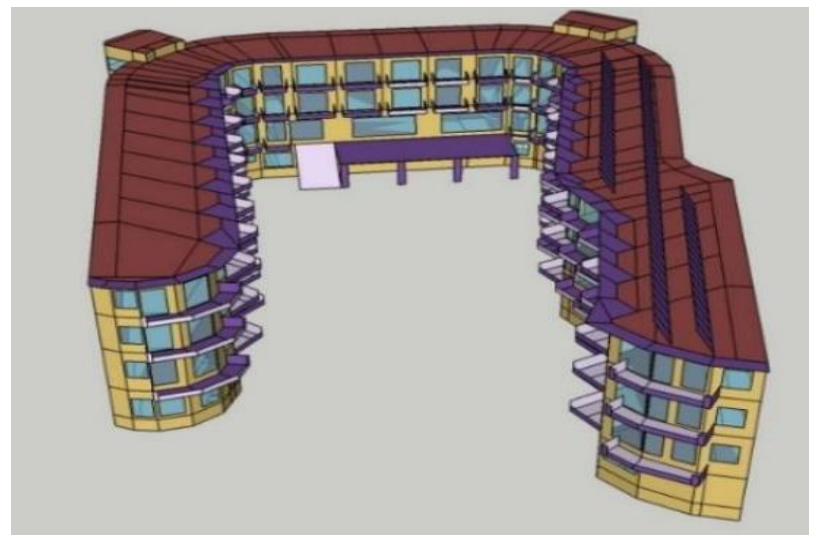

Fig. 1. 3D image of the existing hotel building which has been modeled by OpenStudio.
The technical properties of the building opaque and transparent element of the hotel are listed in the Table 3 below. For window glass of hotel Solar Heat Gain Coefficient (SHGC) is 0,737 and Visible Transmittance (VT) is 0,797 .

Table 3. Technical properties of the building elements.

\begin{tabular}{|c|c|}
\hline Building elements & U Value \\
\hline Exterior wall & 0,38 \\
\hline Indoor floor & 1,828 \\
\hline Outdoor floor & 0,423 \\
\hline Roof & 0,308 \\
\hline Window glass & 2,7 \\
\hline Window frame & 1,3 \\
\hline
\end{tabular}

The orientation of the building to the north is shown in Figure 2.

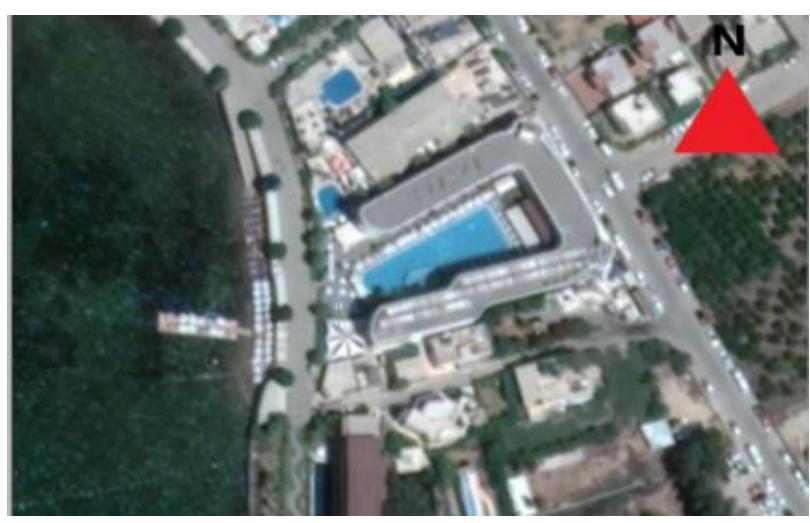

Fig. 2. An image of existing hotel building from the top.

The building's HVAC system was tested using the EPlus v.8.1 dynamic simulation tool. General heating and cooling of the building is carried out using the VRF system. The indoor units in the conditioned areas are connected to the selected VRF outdoor units and these indoor units circulate the indoor air of the environment and condition the environment. The hotel set temperature is $21-26^{\circ} \mathrm{C}$ in the bedrooms, wet rooms, stair halls and corridors are open to the outside is not conditioned. In addition, the sanitary hot water system of the building is provided by an electric boiler with a capacity of $30 * 4$ $\mathrm{kW}$, and 80 solar collectors in the south are supported by the sanitary hot water system. Each of the solar collectors has an active area of $2.1 \mathrm{~m}^{2}$ yield of $83 \%$.

The ventilation strategy of the test building is defined by adhering to the ventilation type of the existing building and is provided in a natural way. The bathrooms in the rooms do not have heating cooling, but only the dirty air is exhausted by the exhaust fan.

The existing building is designed using energysaving led luminaires, and in the public areas such as corridor and wc, the lighting is motion sensor. The lighting system of the test building is screened according to the function of the spaces and is defined in $\mathrm{W}$ per unit area as shown in Table 4 as internal gains.

For the cost of electricity used in cost analysis, unit price of 2014 is obtained from the invoice and received as $0.235878 \mathrm{TL}$.

In this paper, building energy performance analyzes are carried out on two different climatic zones for the 
application example. In the specified test scenarios, the same geometrical form of application is located in Bodrum and Erzurum to represent the hot-humid and cold climate.

The hotel located in Bodrum, is a hotel that serves summer tourism and works for eight months including March and October. Although the local climate is a bit different, the climate data of the central province of Muğla are used in the simulations because of the lack of relevant local climatic data. In this building, user behavior and occupancy rates are defined according to the interviews made with the hotel management.

For cold climate, the hotel building with the same geometrical features and functional spaces assumed to be located in Erzurum Palandöken is suitable for the ski season in November, December, January and February operating four months a year analyzes were performed. Climate data still belongs to the city center of Erzurum.

The zone list includes the setting temperatures of the zones and the internal gain values are listed below in Table 4. Internal gainss from lighting and equipment were obtained from the large-scale reference hotel building data prepared for commercial reference buildings by the United Nations Department of Energy.

The equipment is designed for the minimum equipment in each functional room in the hotel standards. electrical appliances such as kettles, tv, mini fridges, hair dryers for bedrooms. The number of people in the bedrooms and the number of beds available in the hotel is obtained by proportioning the number of beds. The setting temperatures defined for each zone are from DIN EN 18599 benefited from [16].

Table 4. Zone list.

\begin{tabular}{|l|c|c|c|c|}
\hline \multirow{2}{*}{ Zone list } & \multirow{2}{*}{\begin{tabular}{c}
\multirow{2}{*}{ Set } \\
Temperature
\end{tabular}} & \multicolumn{3}{|c|}{ Internal Gains } \\
\cline { 3 - 5 } & & Lighting & People & Equipment \\
\cline { 3 - 5 } & $21^{\circ} \mathrm{C}-26^{\circ} \mathrm{C}$ & 11,84 & 11 & 14,3 \\
\hline Rooms & $16^{\circ} \mathrm{C}-30^{\circ} \mathrm{C}$ & 11,84 & 11 & 14,3 \\
\hline Corridors & $16^{\circ} \mathrm{C}-30^{\circ} \mathrm{C}$ & 11,84 & 11 & 14,3 \\
\hline Staircase & $21{ }^{\circ} \mathrm{C}-26^{\circ} \mathrm{C}$ & 11,84 & 11 & 14,3 \\
\hline Lobby & $21^{\circ} \mathrm{C}-26^{\circ} \mathrm{C}$ & 11,84 & 7,51 & 14,3 \\
\hline Massage & $18^{\circ} \mathrm{C}$ & 12 & 13,5 & 9,01 \\
\hline Fitness & $50^{\circ} \mathrm{C}$ & 11,84 & 12,5 & 14,3 \\
\hline Sauna & - & 11,84 & - & - \\
\hline Toilets & $50^{\circ} \mathrm{C}$ & 12 & 2 & 10 \\
\hline $\begin{array}{l}\text { Turkish } \\
\text { bath }\end{array}$ & - & 9 & - & - \\
\hline Storage & $21^{\circ} \mathrm{C}-26^{\circ} \mathrm{C}$ & 11,84 & 7,64 & - \\
\hline Infirmary & $21^{\circ} \mathrm{C}-26^{\circ} \mathrm{C}$ & 15 & 8,49 & 40 \\
\hline Hairdresser & $21^{\circ} \mathrm{C}-26^{\circ} \mathrm{C}$ & 13,2 & 7,59 & 15,1 \\
\hline Offices & $-5^{\circ} \mathrm{C}-+5^{\circ} \mathrm{C}$ & 9 & - & -10 \\
\hline $\begin{array}{l}\text { Cold } \\
\text { storage }\end{array}$ & $21^{\circ} \mathrm{C}-26^{\circ} \mathrm{C}$ & 12 & 13,5 & 150 \\
\hline $\begin{array}{l}\text { Main } \\
\text { kitchen }\end{array}$ & $21^{\circ} \mathrm{C}-26^{\circ} \mathrm{C}$ & 12 & 2,27 & 10 \\
\hline Restaurant & $21^{\circ} \mathrm{C}-26^{\circ} \mathrm{C}$ & 11,84 & 11 & 14,3 \\
\hline Lounge & $21^{\circ} \mathrm{C}-26^{\circ} \mathrm{C}$ & 11,84 & 11 & 14,3 \\
\hline Foyer & $21^{\circ} \mathrm{C}-26^{\circ} \mathrm{C}$ & 11,84 & 11 & 14,3 \\
\hline $\begin{array}{l}\text { Multipurpose } \\
\text { hall }\end{array}$ & $21^{\circ} \mathrm{C}-26^{\circ} \mathrm{C}$ & 11,84 & 32,01 & 14,3 \\
\hline Cafeteria & & & & \\
\hline
\end{tabular}

The base building is the situation where there are no balconies to shade the building and no heat insulation.
The thickness and the type of heat insulation, glass type, shading element and changing positions are selected as basic analysis parameters. In this paper, the results of 22 simulations including the proposed 20 improvement scenarios, the base building and the existing building were included shown in Table 5. Some abbreviations are used in the tables such as "RW" is rockwool, " $\mathrm{B}$ " is Bodrum, "E" is Erzurum, "Ref" is reflectivity, "Trans" is transmittance, "Med" is middle, "Sol" is solar.

Table 5. Scenarios list.

\begin{tabular}{|c|c|c|c|}
\hline 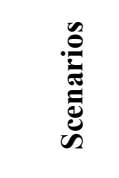 & 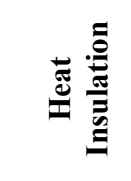 & 常 & 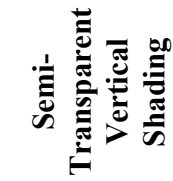 \\
\hline $\begin{array}{l}\text { Base } \\
\text { Building } \\
\end{array}$ & Non & $\begin{array}{c}\text { 4+16air+4 } \\
\text { Clear Glass }\end{array}$ & Non \\
\hline $\begin{array}{l}\text { Existing } \\
\text { Building }\end{array}$ & $5 \mathrm{~cm} \mathrm{RW}$ & $\begin{array}{c}4+16 \text { air }+4 \\
\text { Clear Glass }\end{array}$ & Non \\
\hline S1 B/E & $5 \mathrm{~cm} \mathrm{eps}$ & $\begin{array}{c}4+16 \text { air }+4 \\
\text { Clear Glass }\end{array}$ & Non \\
\hline $\mathrm{S} 2 \mathrm{~B} / \mathrm{E}$ & $8 \mathrm{~cm}$ eps & $\begin{array}{c}+16 \text { air }+4 \\
\text { Clear Glass }\end{array}$ & Non \\
\hline $\mathrm{S} 3 \mathrm{~B} / \mathrm{E}$ & $4 \mathrm{~cm}$ eps & $\begin{array}{c}4+16 \text { air }+4 \\
\text { Clear Glass }\end{array}$ & Non \\
\hline $\mathrm{S} 4 \mathrm{~B} / \mathrm{E}$ & $5 \mathrm{~cm} \mathrm{RW}$ & $\begin{array}{c}4+16 a i r+4 \\
\text { Comfort Type }\end{array}$ & Non \\
\hline S5 B/E & $5 \mathrm{~cm} \mathrm{RW}$ & $\begin{array}{l}\text { 4+16argon }+4 \\
\text { Comfort Type } \\
\end{array}$ & Non \\
\hline S6 B/E & $5 \mathrm{~cm} \mathrm{RW}$ & 6TS+16air+6 Low-e & Non \\
\hline $\mathrm{S} 7 \mathrm{~B} / \mathrm{E}$ & $5 \mathrm{~cm} \mathrm{RW}$ & $\begin{array}{c}\text { 4+12air+4+12air+4 } \\
\text { Sinergy Type }\end{array}$ & Non \\
\hline $\mathrm{S} 8 \mathrm{~B} / \mathrm{E}$ & $5 \mathrm{~cm} \mathrm{RW}$ & $\begin{array}{c}\text { 4+12air+4+12air+4 } \\
\text { Comfort Type }\end{array}$ & Non \\
\hline S9 B/E & $5 \mathrm{~cm} \mathrm{RW}$ & $\begin{array}{c}4+16 \text { air }+4 \\
\text { Clear Glass } \\
\end{array}$ & $\begin{array}{c}\text { MedSolRef } \\
\text { MedSolTrans } \\
\end{array}$ \\
\hline $\mathrm{S} 10 \mathrm{~B} / \mathrm{E}$ & $5 \mathrm{~cm} \mathrm{RW}$ & $\begin{array}{c}4+16 \text { air }+4 \\
\text { Clear Glass } \\
\end{array}$ & $\begin{array}{c}\text { HighSolRef } \\
\text { LowSolTrans }\end{array}$ \\
\hline S11 B & $5 \mathrm{~cm} \mathrm{RW}$ & $\begin{array}{c}4+16 \text { air }+4 \text { Clear } \\
\text { Glass }\end{array}$ & $\begin{array}{l}\text { LowSolRef. } \\
\text { HighSolTrans }\end{array}$ \\
\hline S12 B & $5 \mathrm{~cm} \mathrm{RW}$ & $\begin{array}{c}\text { 4+16air+4 } \\
\text { Clear Glass }\end{array}$ & $\begin{array}{l}\text { LowSolRef } \\
\text { LowSolTrans }\end{array}$ \\
\hline S13 B & $5 \mathrm{~cm} \mathrm{RW}$ & $\begin{array}{c}4+16 \text { air }+4 \\
\text { Clear Glass }\end{array}$ & $\begin{array}{c}\text { LowSolRef } \\
\text { MedSolTrans }\end{array}$ \\
\hline S14 B & $5 \mathrm{~cm} \mathrm{RW}$ & $\begin{array}{c}4+16 a i r+4 \\
\text { Clear Glass }\end{array}$ & $\begin{array}{c}\text { MedSolRef } \\
\text { LowSolTrans }\end{array}$ \\
\hline S15 E & $8 \mathrm{~cm}$ eps & $\begin{array}{c}\text { 4+16air+4 } \\
\text { Comfort Type } \\
\end{array}$ & Non \\
\hline S16E & $8 \mathrm{~cm} \mathrm{eps}$ & $\begin{array}{l}4+16 \text { argon }+4 \\
\text { Comfort Type }\end{array}$ & Non \\
\hline S17E & $8 \mathrm{~cm} \mathrm{eps}$ & 6TS+16air+6 Low-e & Non \\
\hline S18 E & $8 \mathrm{~cm}$ eps & $\begin{array}{c}\text { 4+12air+4+12air+4 } \\
\text { Sinergy Type }\end{array}$ & Non \\
\hline S19E & $8 \mathrm{~cm} \mathrm{eps}$ & $\begin{array}{c}\text { 4+12air+4+12air }+4 \\
\text { Comfort Type }\end{array}$ & Non \\
\hline S20 E & $10 \mathrm{~cm} \mathrm{eps}$ & $\begin{array}{c}4+16 \text { air }+4 \\
\text { Clear Glass } \\
\end{array}$ & Non \\
\hline
\end{tabular}

\subsection{Findings of the energy and cost analysis for Bodrum}

Considering the annual energy consumption of all the scenarios proposed for Bodrum, it is seen that heating energy consumption is quite low due to the seasonal work of the sample hotel. Current situation total 171 $\mathrm{kWh} / \mathrm{m}^{2}$ while the lowest consumption amount obtained with individual improvements is S9 with $119,7 \mathrm{kWh} / \mathrm{m} 2$. 
The energy consumption results for all scenarios are given in Table 6. The results of global cost analysis for chosen scenarios are given in Table 7.

Table 6. The energy consumption results for Bodrum.

\begin{tabular}{|l|c|c|c|c|}
\hline & & & \\
\hline
\end{tabular}

Table 7. The global cost findings for Bodrum.

\begin{tabular}{|c|c|}
\hline Scenarios & $\begin{array}{c}\text { Global Cost } \\
\text { TL }\end{array}$ \\
\hline S7 & 3.175 .789 \\
\hline S11 & 3.168 .519 \\
\hline S8 & 3.049 .978 \\
\hline S5 & 3.020 .706 \\
\hline S4 & 2.977 .500 \\
\hline S13 & 2.809 .465 \\
\hline S9 & 2.773 .709 \\
\hline S6 & 2.737 .991 \\
\hline S12 & 2.453 .644 \\
\hline S14 & 2.435 .638 \\
\hline S10 & 2.366 .867 \\
\hline
\end{tabular}

\subsection{Findings of the energy and cost analysis for Erzurum}

According to the findings of the scenarios for winter season active Erzurum sample, this time, the test building is located in the cold climate and it is seen in the results of the analysis that the heating consumption is at quite high levels compared to the other climate zone despite the high internal gains it has due to the function of the building. Among the scenarios determined, S18 has the highest energy efficiency shown in Table 8 . In this case, both insulation material and thickness as well as glass type can be bent and multiple measures can be achieved by $25.7 \%$ improvement.

The global costs were assessed for the Erzurum sample, which was assumed to operate only during the ski season, and the lowest cost was obtained with S7. $\mathrm{S} 18$, where energy consumption is the lowest while the highest cost was observed in S7 shown in Table 9.
The emergence of situations in which energy efficiency and cost-effectiveness differed considerably indicated that the analyzes should be evaluated together.

Table 8. The energy consumption results for Erzurum.

\begin{tabular}{|c|c|c|c|c|}
\hline : & 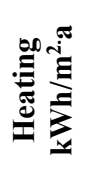 & 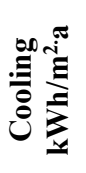 & 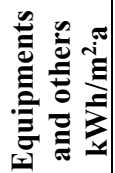 & 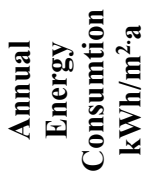 \\
\hline $\begin{array}{l}\text { Base } \\
\text { Building }\end{array}$ & 55,4 & 0,6 & 58,8 & 117,2 \\
\hline $\begin{array}{l}\text { Existing } \\
\text { Building }\end{array}$ & 47,7 & 0,9 & 53 & 104 \\
\hline S2 E & 45,1 & 1,1 & 51,1 & 99,6 \\
\hline S20 E & 44,4 & 1,2 & 50,6 & 98,4 \\
\hline S4 E & 46,3 & 0,8 & 51,7 & 101,2 \\
\hline S15 E & 42,7 & 1 & 49,2 & 95,3 \\
\hline S5 E & 44,4 & 0,9 & 50,4 & 98 \\
\hline S16 E & 40,7 & 1,1 & 47,7 & 92 \\
\hline S7 E & 41,3 & 1 & 48,1 & 92,8 \\
\hline S18 E & 37,7 & 1,4 & 45,6 & 87,1 \\
\hline S8 E & 43,4 & 0,9 & 49,6 & 96,3 \\
\hline S19 E & 39,8 & 1,2 & 47 & 90,3 \\
\hline S10 E & 62,4 & 0,6 & 64,2 & 129,6 \\
\hline S9 E & 56,6 & 0,6 & 59,7 & 119,3 \\
\hline S17 E & 49,3 & 0,8 & 51,8 & 104,2 \\
\hline
\end{tabular}

Table 9. The global cost findings for Erzurum.

\begin{tabular}{|c|c|}
\hline Scenarios & $\begin{array}{c}\text { Global Cost } \\
\text { TL }\end{array}$ \\
\hline Base Building & $\mathbf{2 . 2 5 1 . 9 5 6}$ \\
\hline Existing Building & $\mathbf{1 . 9 9 8 . 5 1 4}$ \\
\hline S7 & 1.759 .969 \\
\hline S8 & 2.054 .667 \\
\hline S5 & 2.030 .452 \\
\hline S4 & 2.080 .774 \\
\hline S9 & 2.258 .309 \\
\hline S10 & 2.556 .568 \\
\hline S19 & 2.240 .325 \\
\hline S20 & 2.270 .105 \\
\hline S2 & 2.179 .868 \\
\hline S15 & 2.177 .435 \\
\hline S16 & 2.120 .209 \\
\hline S18 & 2.051 .142 \\
\hline
\end{tabular}

\subsection{Determination of energy and cost optimum improvement scenario}

The selection of the optimum improvement scenario is done by graphing the primary energy in the $\mathrm{X}$ axis and the global cost values on the $\mathrm{Y}$ axis from the findings obtained from the analysis. With the help of this graph, the scenarios of the current situation and test are seen comparatively. Among the scenarios, the option, which has the lowest energy consumption at the optimum cost, is taken as the basis for the application.

However, choosing between scenarios where energy efficiency and global costs are very close to each other will be possible by other reasons such as the aesthetic or process that the investor / designer will consider. 
Based on all findings, the measures to be taken in order to increase the energy and cost effectiveness of the hotels that are located in different climate regions and serve in different tourism seasons vary.

In the case of Erzurum, S18 was chosen as the costoptimized improvement scenario among the tested scenarios because the primary energy consumption was the lowest scenario shown in Figure 3.

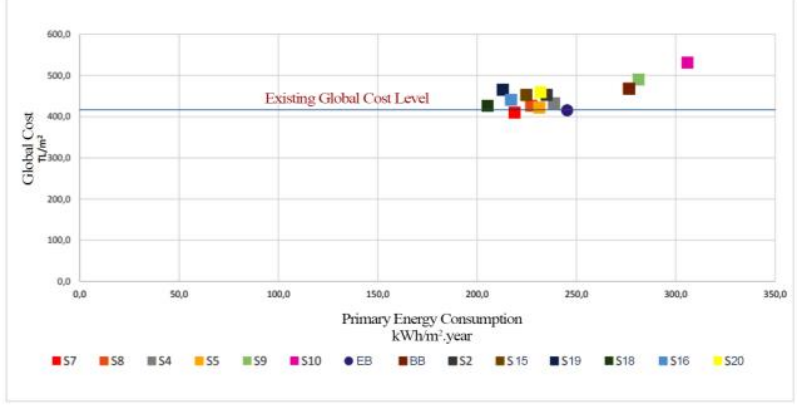

Fig. 3. Energy-Cost optimal graphic for Erzurum.

\section{Conclusion}

In this paper, it has been developed to increase the energy and cost efficiency of the existing hotel stock as a general framework, and by following this method, it allows to test different alternatives and to determine the optimum alternative among them. In different climatic zones, in different building forms, different thermal zones are identified, and possible improvement packages have been identified with the method developed for hotels with different capacity and usage and with a fluid structure that can reach the purpose for the functional spaces.

Based on the proposed approach, the results of the analysis of the characteristics of the hot humid climate region and the high internal gain values in the complex buildings of the hotel are mainly highlighted by the analyzes of the cooling loads. The energy efficiency of the improvement scenarios based on the reduction of solar gains for this climate zone is high.

According to the energy analysis of the same current building, which only serves the winter period, in the cold climate zone (Erzurum), despite the high internal gains caused by the function and capacity of the building, it is seen that the purpose of the weighted consumption in the building is heating. In this case, both insulation material type and thickness as well as glass type can be bent and through multiple measures can be achieved by $25.7 \%$ improvement for energy efficiency.

This time, instead of solar control, it has been found that the role of window type and heat exhaustion improvement scenarios, which minimize heat losses, increased in cost optimal energy efficiency.

Through the results and comparisons obtained from the paper, the applicability of the approach is tested. When we look at the findings obtained from the energy and cost analysis of existing building and improvement scenarios, it is observed that the role of energy efficiency parameters and the rate of efficiency of the same parameters vary according to the difference of the annual working schedules of hotel buildings located in different climate regions.

EPBD Recast (2012) developed the method of calculation for the EU member and candidate countries in accordance with their national conditions and determined the optimum cost levels of energy performance requirements in the buildings with this method the building energy performance is required to be integrated into the calculation methods and approximately zero energy building [17].

For the improvement of hotel buildings with a high potential for energy conservation, specific remediation measures according to the study timetable specific to the climate region should be determined at the national level.

In order to evaluate the energy efficiency of hotels, it is urgent to determine the reference hotel building which is not yet defined in our country.

Legislative arrangements should be made for the replication of the improvement measures to include active systems and the implementation of the improvements based on the relevant invoice values.

\section{References}

1. Energy Policies of IEA Countries: Turkey 2016 Review, 486, 2016.

2. http://www.tuik.gov.tr/PreTablo.do?alt_id=1029

3. Doğal Hayatı Koruma Derneği "WWF Raporu" http://www.wwf.org.tr/basin_bultenleri/raporlar/201 2.

4. TÜİK, (2006). Sektörel Enerji Tüketim İstatistikleri, 2006.

5. http://yigm.kulturturizm.gov.tr/TR,9854/sinir-giriscikis-istatistikleri.html, 2018.

6. Energy Standard for Buildings Except Low Rise Residential Buildings, US, ASHRAE 90.1,2004.

7. Yılmaz Ve Diğerleri, Binalarda Maliyet Optimum Enerji Verimliliği Seviyesi için Türkiye Koşullarına Uygun Yöntemin ve Referans Binaların Belirlenmesi, Proje No:113M596, TÜBİTAK, 2015.

8. Ganiç Sağlam ve Yılmaz, Avrupa Birliği Direktifi Doğrultusunda Binalarda Yaklaşık Sıfır Enerji Düzeyinin Akdeniz Ülkesi Olan Türkiye'de Konut Binaları İçin Belirlenmesine Yönelik Uygulama Örneği, 12. Ulusal Tesisat Mühendisliği Kongresi, İzmir, Nisan 8-11, 2015.

9. A Common Definition for Zero Energy Buildings, The National Institute of Building Sciences, Deparment of Energy, 2015.

10. Prof.Dr.A.Zerrin Y1lmaz, En 13790 ve BepTr Net Enerji Hesaplama Yöntemi. 2010.

11. Atmaca M., Avrupa Birliği Bina Enerji Performans1 Direktifi'nin Türkiye'deki Mevcut Otel Binaları İçin Uyarlanmasına Yönelik Bir Yaklaşım, Doktora Tezi, ITU, 2017. 
12. Energy performance of buildings. Overall energy use and definition of energy ratings, BS EN 15603:2008

13. Yeşil Bina Sertifika Kılavuzu Yeni Konutlar Ver. 0. Ç. D. Y. B. Derneği, 2013.

14. Ashrafian, T., A New Approach to Define Economically Applicable Energy Efficient Retrofit Solutions for Residential Buildings in Turkey, (Doktora Tezi). İstanbul Teknik Üniversitesi, Fen Bilimleri Enstitüsü, İstanbul, 2016.

15. Yilmaz A.Z., Ashrafian T., Ganic N., Gali G., Akguc A., Binalarda Maliyet Optimum Enerji Verimliliği Seviyesi İçin Türkiye Koşullarına Uygun Yöntemin Ve Referans Binaların Belirlenmesi, Proje No:113M596, TÜBİTAK, 2015.

16. DIN18599 - Energy Performance of Buildings,2011.

17. Directive 2010/31/EU, Directive of The European Parliament and of The Council of 19 May 2010, The Energy Performance of Buildings (Recast), 2010. 